\title{
The controlled allergen challenge experience: comparison of allergic upper respiratory symptoms in the environmental exposure unit (EEU) and during seasonal exposure
}

\author{
AK Ellis*, E Rafeiro, JD Ratz, JH Day \\ From Canadian Society of Allergy and Clinical Immunology Annual Scientific Meeting 2009 \\ Halifax, Canada. 22-25 October 2009
}

\section{Background}

Traditional assessment of seasonal allergic rhinitis (SAR) medication efficacy utilizes randomized controlled trials over 2-4 weeks in season. An additional study method employs single-dose responses using controlled allergen challenge such as the Environmental Exposure Unit (EEU). A comparison of allergic symptoms generated by controlled allergen challenge to those occurring in ragweed season symptoms has not been done.

\section{Methods}

1821 subjects with known SAR to ragweed were mailed a survey during the third week of ragweed season, soliciting the nature and severity of SAR symptoms. Subjects participating in a subsequent controlled allergen challenge study using the EEU, were again asked to complete a similar survey that documented symptoms generated in this model. Those who completed both surveys comprised the primary analysis group.

\section{Results}

550 subjects completed the ragweed season survey, 516 subjects completed the EEU survey, and 270 completed both. Symptoms generated by EEU exposure were similar to those elicited during ragweed season, with the exception of cough ( $68 \%$ vs. $27 \%$, respectively, p $<0.01)$. Subjects reported that symptoms were more severe in the EEU than those experienced on a typical ragweed season day, but less severe than those during peak ragweed season days.

\footnotetext{
* Correspondence: ellisa@kgh.kari.net

Department of Medicine, Queen's University and Division of Allergy \& Immunology, Kingston General Hospital, Kingston, ON, Canada
}

\section{Conclusion}

Allergic upper respiratory tract symptoms produced during controlled ragweed pollen exposure in the EEU were similar in nature and degree to those experienced during ragweed season, supporting evidence that the EEU is a valid model for studying SAR.

"This study was self-funded.

Published: 12 May 2010

doi:10.1186/1710-1492-6-S1-P28

Cite this article as: Ellis et al:: The controlled allergen challenge experience: comparison of allergic upper respiratory symptoms in the environmental exposure unit (EEU) and during seasonal exposure. Allergy, Asthma \& Clinical Immunology 2010 6(Suppl 1):P28.

\section{Submit your next manuscript to BioMed Central and take full advantage of: \\ - Convenient online submission \\ - Thorough peer review \\ - No space constraints or color figure charges \\ - Immediate publication on acceptance \\ - Inclusion in PubMed, CAS, Scopus and Google Scholar \\ - Research which is freely available for redistribution \\ Submit your manuscript at www.biomedcentral.com/submit}

